Faculty of Law, University Josip Juraj Strossmayer, Osijek, Republic of Croatia

UDK: 331.5.024.5(497.6:485:489)

Рад примљен: 18.10 .2020$.

Рад прихваћен: 17.12.2020.

\title{
RESPONSIBLE EMPLOYMENT POLICY: Comparative Analysis of Croatian, Swedish and Danish Active Labour Market Policies ${ }^{* *}$
}

\begin{abstract}
In the past decades, the reduction of unemployment has been one of the crucial areas of social policies of the EU Member States because it is a key to economic growth and development. Taking into consideration the fast-changing labour market needs and the rapid transformation of labour relations, European public employment services are continuously creating new measures of active employment, with the aim to assist as many unemployed beneficiaries as possible and to swiftly re-integrate them into the labour markets. The main goal of active labour market programs is to make the matching process more efficient and to increase the number of successful matches of job vacancies and job seekers. Referring to examples of selected active employment measures in Croatia, Sweden and Denmark, this paper provides a comparative analysis of active labour market measures. The paper is divided into four sections. Section 1 provides an overview of measures to reduce unemployment; section 2 outlines the purpose of active labour market measures; section 3 provides a comparative analysis of five active labour market programs in Croatia, Denmark and Sweden, and a brief description of new activation strategies during Covid-19 in Croatia. The conclusion is that the creation of impactful social policies for employment substantially rests on conducting comprehensive analysis of the impact of active labour market measures from the perspective of new employment
\end{abstract}

\footnotetext{
${ }^{*}$ hspadina@pravos.hr

** The paper was presented at the International Scientific Conference "Responsibility in Legal and Social Context", (online),organized by the Faculty of Law, University of Niš, on 18 September 2020.
} 
opportunities and_the acquisition of new skills, as well as the analysis of the level of social inclusion of jobseekers.

Keywords: active labour market policies, activation strategies, unemployment, social policy, Covid-19.

\section{Measures to Prevent Unemployment}

Unemployment is one of major social risks because it can lead to the poverty, discrimination and social exclusion. Unemployment is a result of discrepancies between education attainment and labour market needs, and a mismatch of labour supply and labour demand (Spicker, 2015: 100). Unemployment was traditionally seen as a structural problem that could be solved by job creation, economic development and strengthening of the social protection system; but, gradually, a more individual approach was taken in which special measures were developed aimed at "activating" the unemployed and reintegrating them into the labour market(cf. Gilbert, Von Voorhuis, 2001 in Spicker, 2015:85; Hudson, et al, 2015:42).

Responsible social policies in the area of reducing unemployment usually comprise two sets of measures: passive or reactive policies (unemployment benefits aimed at income protection), and active policies (vocational trainings, apprenticeships, youth programs, subsidized employment, job retention programs, measures for disabled workers, re-skilling or requalification programs, public works, specially designed programs for vulnerable categories of workers) ( $c f$. Obadić, 2003:535; Hudson, et al, 2015:37-38). Too generous unemployment benefits might discourage the unemployed people from job seeking and stimulate them to remain unemployed, while insufficient ones would lead to income insecurity and poverty. It is a task of a modern state to engage in the development of targeted and purposeful policies for labour market reintegration, and to perform periodic evaluation and impact assessment of each measure, together with the analysis of impact of labour market regulations, education policies, family policies and immigration policy on demand for employment (Hudson, et al., 2015: 40). Thus, states have the task to create a right set of measures aimed at reducing unemployment; but, in times of the Covid-19 pandemic, it is further exacerbated with significantly higher rates of unemployment due to lockdowns and quarantines.

\section{Purpose of Active Labour Market Programs}

The primary purpose of active employment measures is to contribute to a wellfunctioning labour market by assisting unemployed people to find work, to 
provide services to employers seeking labour or wishing to retain employees, and to support people with special needs, or a reduced ability to work, to find work (Danish Public Employment Service, 2020). Active labour market policy includes measures such as employment training and publicly subsidized employment, direct job creation, enterprise or work incentives, and employment rehabilitation ( $c f$. Immervoll, Scarpetta, 2012: 1-2; Hill, Irwing, 2020: 97). The purpose of these measures is to strengthen people's motivation to look for and make use of existing earnings opportunities, to address specific employment barriers on the labour-supply side by improving the capabilities of jobseekers, and to expand the set of earning opportunities that are available and accessible to jobseekers (Immervoll, Scarpetta, 2012:1-2). On the other hand, employment incentives and rehabilitation programmes incentivize the unemployed to accept jobs, while high expenditure on active labour market policies in the areas of employment incentives, rehabilitation measures and training can compete and, more importantly, diverge from public responses to unemployment, such as a job creation (cf. Vlandas, 2013; Griggs, 2014). Therefore, the creation of activation strategies has to be approached with particular caution and strategic perspective of achieving higher employment rates and social inclusion of jobseekers, but job creation cannot be replaced by active labour market measures.

Active labour market policies and measures are closely linked to the receipt of income-replacement benefits, and they are usually made conditional on compliance with employment- and job-search related requirements(cf. Immervoll, Scarpetta, 2012: 3). Hill and Irving argue that northern countries have introduced "punitive range of job-seeking conditionality attached to the receipt of income support measures...grounded on the assumption that...labour supply rather than labour demand is the problem and, therefore, adaptive behaviours by employees are required more than those by employers"(Hill, Irving, 2020: 98). This remark is important when we analyse active labour market policies and measures adopted to implement such a policy. We can notice a trend in making job-seeking conditionality more stringent upon the unemployed who are expected to be as flexible as possible, willing to engage in professional specialization, acquire new skills and, if necessary, even change profession if this is required by the employers or labour market needs. In Sweden, for example, the initial aim of active labour market programs was to transfer labour from stagnating low productivity sectors to expanding high-productivity sectors through training programmes and other mobility-enhancing measures (Calmfors, 2001:80).

We also have to be aware of the risks of benefit dependency, the loss of human capital among the long-term unemployed people and, ultimately, of higher public spending on labour market and social policies; in particular, if unemployment benefits and the possible use of activation measures for job seekers are long- 
lasting or of indefinite duration, we shall try to prevent the negative effects when creating employment social policies (Immervoll, Scarpetta, 2012: 3). We should also not underestimate the fact that active labour market policies often do not adequately interact with other types of public interventions (e.g. in education systems), which can potentially limit their reach and effectiveness (Pignatti, Van Belle, 2018: 2), given that even perfect active labour market programs cannot replace education credentials for which there is high labour demand. The lack of interaction and mutual correlation between other parts of public social policy and employment policies can be detrimental not only to the implementation of the active labour market measures but also to the overall employability of the job seeker, leading possibly to his/her non-employable status in case of extreme discrepancy between education attainment and labour market demand. Finally, complementarity and interaction between passive and active labour market policies (cf. Pignatti, Van Belle, 2018: 2) needs to be closely examined and evaluated when creating targeted and impactful employment measures.

There are multiple benefits of participation in the active labour market program. In addition to the increase in competitiveness, skills and employability in general, we should not neglect another very important aspect, which implies that active labour market programs may help to maintain the job seeker's motivation to seek work actively, i.e. it may counteract the discouraged-worker effect of unemployment (Calmfors, et al, 2001:78). Participants in active labour market programs may experience a higher degree of psychological well-being than the openly unemployed people because programme participation is considered more meaningful (Korpi, 1997). This is particularly important for long-term unemployment where negative effects of exclusion from the labour market and low-level of productivity are multiplied.

\section{Comparative Analysis of Croatian, Swedish and Danish Active Labour Market Policies}

Croatia currently has a total of 150,139 registered unemployed persons and 10,314 available jobs in the labour market; prior to the Covid-19, the quota for employment of foreign workers in 2020 was set to 78,470 labour permits and 38,794 beneficiaries of active labour market measures. Currently, we have six active employment policy programs, and three Covid-19 related activation programs. The Government of the Republic of Croatia adopts strategic plans and programs, including measures of active employment policy which is regulated by the provisions of Articles 34-43 of the Labour Market Act (Official Gazette, No. $118 / 18,32 / 20$ ). In 2019 , the unemployment rate was $6.6 \%$, but we need to emphasise that decrease of unemployment rate from $17.3 \%$ in 2014 and $16.2 \%$ 
in 2015 (Croatian Bureau of Statistics, 2018) is not the result of efficient labour market policies but rather of very active emigration of Croatian labour force towards other EU Member States.

Sweden is one of the most active countries in creation and implementation of programs aimed at preventing and reducing unemployment. In 2019, the unemployment rate was $6.48 \%$. The Swedish government is currently implementing six different categories of active labour market measures, including employment with support, work experience placement, start-up business incentives, vocational training, Swedish for immigrants, and general training and education.

Denmark had an unemployment rate of 3.7\% in 2019. Targeting all categories of unemployed persons, their active employment measures include: education, guidance and upgrading of skills; wage subsidies at public or private employers, and practical work training at public and private enterprises.

\subsection{Traineeship and Internship Activation Programs or Subsidies for Young Job Seekers}

\subsubsection{Croatia}

There are three active labour market programs for young jobseekers: traineeship, internship, and activation program for the unemployed. The cost of internship is fully subsidized only to public offices, while in the private sector it covers half of the salary of trainees for the first year of the employment. In traineeship programs, which can last up to six months, the cost of employer's mentoring and exam preparatory teaching (if applicable) is covered, while the beneficiary can claim transportation costs. The purpose of the activation program is to train unemployed persons to acquire practical knowledge and skills necessary for their active inclusion in the labour market; the measure covers transportation costs and financial aid for the jobseeker. Activation program can last up to 2 months, while the individual participation of candidates is limited to 15 days (Croatian Public Employment Service, 2020).

\subsubsection{Sweden}

Sweden has an extensive program of activation measures designed for young jobseekers. Programs target jobseekers above the age of 25 who are unemployed or at risk of becoming unemployed, jobseekers under the age of 30 with a disability that affects their ability to work, jobseekers who are 18 years old, unemployed and need extra support to enter the labour market, and newcomers to Sweden who take part in establishment programs and those participating in speciali- 
zed youth employment programs. Important part of all activation measures is that they include not only job placement but also competence assessment by a supervisor during the work experience, which takes up to three weeks and can be done at a workplace, a vocational college or a similar place. Jobseekers need to find a workplace either with private or public employers, on their own or with the help of public employment service, which also plans the structure of the work experience together with the beneficiary and the employer, consulting the trade union. All persons participating in this measure are entitled to activity support, development allowance or establishment allowance, a certificate from the workplace which describes the work experience and whether the work experience programme includes an assessment of the professional competence in writing.

An introductory job is available for persons who have been unemployed for a long period of time and for those who recently arrived in Sweden. It can be combined with studies, training and education, vocational course, and upper secondary school studies in order to take the upper secondary school exam or studies in Swedish. The Employment Office, together with the jobseeker and employer, assesses whether a workplace is suitable; if the results are positive, the employer receives the wage subsidy. The common duration of an introductory job is up to 12 months, which can be extended to 36 months if the Employment Office assesses that a person needs continued support(Swedish Public Employment Service, 2020).

\subsubsection{Denmark}

In Denmark, there are two equivalent activation measures for young jobseekers. The first one is practical work training at public and private enterprises, which can be used to re-train jobseekers and upgrade their qualifications. The jobseeker continues to receive unemployment insurance benefits for the duration of an internship to develop the skills. The second program is an adult apprenticeship scheme for those who have turned 25 years at the commencement of the programme. Employers are eligible for a subsidy for the salary paid in the practical training period when they enter into a training agreement with jobseekers.

Another youth activation program is the "youth guarantee initiative", based upon early intervention after three months of unemployment, as compared with six months for older unemployed persons. The program entails mandatory activation of those under the age of 30 and a stronger focus on motivating young people without a vocational education to enter one. Interventions target young people who are inactive on the labour market but who are not registered as unemployed persons. For unskilled young unemployed persons, the focus is 
on improving their formal skills through vocational education in the regular educational system. Unemployed persons under the age of 25 who have not completed secondary education are under the obligation to undertake regular tests of skills in reading, writing, and arithmetic. If the test reveals shortcomings, the jobseeker is obliged to participate in a relevant training programme. Unemployed persons who face multiple challenges are categorised as 'ready for activation', which entitles them to receive additional support of a coordinating case-worker at the job centre and job training or 'building bridge to education', and a mentor support.

Denmark also has active labour market measures for youth between the age of 15-17,who are obliged to be in education, employment or another activity in accordance with their personal education plan. When a young person leaves primary and lower secondary education to begin vocational or upper secondary education, the youth guidance centre must assess whether he/she possesses the educational, personal and social skills to do so. In case of young people who are assessed as not yet being ready to move into further education, the municipality must provide training or other assistance needed in order to help them achieve a positive assessment. The youth guidance centres provide guidance services for young people up to the age of 25 , focusing in particular on the transition from compulsory to upper secondary education or to the labour market (Danish Agency for Labour Market and Recruitment, 2020).

\subsubsection{Comparative analysis}

If we analyse the basic requirements for implementation of activation measures for young jobseekers, we can notice that in Sweden and Denmark there is a strong emphasis on initial assessment of professional competences and a subsequent mandatory evaluation of achieved competencies, and development of a personal education plan. The main reasons for the development of youth labour market activation programs are exactly what Swedish and Danish programs have at their core: opportunity for an inexperienced jobseeker to enter the labour market and acquire a certain level of professional competencies. If activations measures do not end with thorough assessment of increase in competency level, they are considered not to have achieved the intended goals. In a survey aimed at analyzing the subsidized internship programs in Croatia between 2010 and 2013, one sixth of surveyed beneficiaries pointed out that they were conducting menial jobs, unrelated to their education, and did not learn enough, mainly working in public offices (Croatian Public Employment Office, Ipsos, 2016:32-33). If initial assessment and mandatory evaluation of internship performed and if negative experiences should lead to the future exclusion of employers from internship 
subsidies, this measure can become purposeful and result in increase of professional competencies of young jobseekers.

Further, the Danish obligation of conducting regular tests and introducing obligatory training in reading, writing and arithmetic for insufficiently educated youth is a good example of providing additional education while implementing activation programs. The practice of inclusion of young people who are not registered as unemployed into the activation programs and vocational training shows that activation programs can achieve much more if we open them to all young beneficiaries because this is how social exclusion can be successfully mitigated.

\subsection{Active Labour Market Programs for Disabled Job Seekers}

\subsubsection{Croatia}

In Croatia, the Employment Office currently does not have any active labour measures specifically designed for the integration of disabled persons into regular jobs, apart from the special Covid-19 measure to retain all employed in sheltered employment (integrative workshops) and the general provision of preferential access to jobs in public offices, if disabled person is equally qualified.

In Croatia, 496,646 persons are registered as disabled. There is a total of 11,529 employed disabled persons, and a total of 5,498 registered unemployed persons; $30 \%$ of the latter are without any working experience (Ombudsperson for Persons with Disabilities, 2020: 135). It is difficult to understand why Croatia, as an EU State which ratified the Convention on the Rights of Disabled Persons in 2007 (Article 27 regulates the obligation to promote employment of disabled persons), does not currently have any specialized active labour market program for employment of disabled persons in regular jobs, apart from self-employment subsidy.

According to the Ombudsperson's 2019 report, the most used general activation measure by disabled people was self-employment support. The Institute for Professional Rehabilitation also covers subsidies for sustainable self-employment of disabled persons. In the last year's report, the Ombudsperson for disabled persons emphasized a large disparity between the number of people with disabilities in the working age and the number of people with disabilities who are active jobseekers, as well as a lack of social inclusion programs for disabled persons reported by the Professional Rehabilitation Centres (Ombudsperson for Persons with Disabilities, 2019: 126). 


\subsubsection{Sweden}

Sweden has six active labour market programs specifically created for disabled jobseekers, and each of them is an example of excellent state policy for labour integration of persons with various degrees of disabilities.

The first program is a grant for personal assistants by which disabled jobseekers can get support and help from a person at the workplace, if they have reduced working capacity. The purpose of the program is to give a grant to the employer who then allocates staff for the role of personal assistant in order to make the job easier for disabled persons and to ensure that he/she actually keeps a job. The personal assistant acts as a support for a worker in repetitive tasks or work situations that disabled workers cannot manage on their own. The grant can also be used for disabled persons to participate in a programme or in school's practical orientation in working life. The grant is applicable to self-employed disabled persons under the same conditions; if they have a disability that causes significant communication difficulties, the grant amount can be doubled.

The second available activation program is wage subsidy for disabled workers, with three types of wage subsidies: to develop the competence and ability to work in order to facilitate job seeking or studying, to increase chances of getting and keeping a job that suits jobseekers' competence and skills, and to ensure security in employment for those with a need for long-term support to get and keep a job. This measure has a strong component of competence development, supervision and adaptation of work. Together with a jobseeker, the Employment Service draws up a plan on how he/she can increase the ability to work and regularly ensures follow-up support to the employed and the employer. Initially, this is a one-year long incentive, but the Employment Service has set as a goal the conversion of subsidized employment into regular non-subsidized employment.

The third activation program is psychosocial adjustment support for jobseekers who feel uncomfortable in social situations at work or unsure about what psychosocial requirements apply in the workplace. The Employment Service assesses whether psychosocial adjustment support is appropriate by getting in touch with the employer and psychologist or social consultant, who jointly assess how the psychosocial environment in the workplace and the psychosocial demands affect the work performance of a jobseeker (Swedish Public Employment Service, 2020).

The fourth activation program for disabled people is protected work at a public employer, which entails specially adapted, subsidized and fixed-duration job, with a goal to develop the beneficiary's ability to work and improve the chances of the disabled person to get a regular job. The Employment Service, together 
with jobseeker and the employer, assesses the suitability of a workplace and tasks, and provides regular follow-up support to the jobseeker and the employer.

The fifth available program involves a special support person who helps disabled persons to train for tasks, provides other things that are needed at the introductory stage, and ensures a follow-up support during job search and at the outset of employment. The support comes in two parts: introductory support of six months, and a follow-up support for maximum of one year after the start of the employment.

The sixth available program includes individual pedagogical support when a disabled person participates in training and education programmes. The jobseeker is supported by a person who can help structure the course of study, study techniques and learning approach; the support can be complemented with various aids and facilities (such as: spelling programmes, speech synthesis software, preparatory training and education, labour market training or high school education). The initial plan includes specific needs of and the support for the jobseeker, while continued guidance and follow-up support are provided during the training or education programme.

Finally, sheltered employment is available at the state-owned company Samhall. They train up to 1,500 employees per year and match them to the right jobs and the right co-workers in cleaning, care, logistics and manufacturing. The long-term aim is that a jobseeker becomes able to get a regular job with another employer (Swedish Public Employment Service, 2020; Samhall, 2020).

\subsubsection{Denmark}

Denmark has a whole range of particular measures for placing disabled persons in employment, including: access to personal assistance, wage subsidies for employers, preferential access, and counteractions towards differential treatment. The Employment Service supports the municipalities to help unemployed disabled people enter the labour market. Subsidies may be granted to a business for the wages of a personal assistant for a disabled employee. Personal assistance can be offered to unemployed people, wage earners and self-employed businesspersons who have a need for special personal assistance on account of physical or mental handicap. The objective of the scheme is to offer persons with disabilities the same possibilities of pursuing a trade or a profession as persons without disabilities. The role of this personal assistance is to assist the disabled employee with work-related tasks, for the performance of which he/ she requires special personal assistance due to his/her functional impairment. 
Support may also be offered to employees who, due to permanent and severe physical or mental handicap, require personal assistance outside normal working hours in order to take part in general supplementary and further training in connection with the job in question. The objective of these compensation schemes is to enhance and stimulate the possibility of employing persons with disabilities and retaining them in the labour market, and to offer them the same possibilities of pursuing a trade or profession as persons without disabilities.

Wage subsidies for the employment of newly educated persons are developed with the aim of gradually integrating disabled persons who have completed an educational programme of at least 18 months' duration, which can entitle such individuals to membership in an unemployment insurance fund. This support may be granted to a public or private employer for a period of up to two years after the completed educational programme. Employment with subsidies will only be approved if the person has not succeeded in obtaining employment in the professional field for which the education programme has qualified him or her.

According to the Danish Act on Active Employment Measures, subsidies are also granted for aids, tools, small-scale workstation design and layout, or teaching equipment (Danish Agency for Labour Market and Recruitment, 2020).

\subsubsection{Comparative analysis}

Integration of disabled persons into the regular labour market should be a goal of all developed societies. Sheltered employment has numerous positive aspects as the entry point to the labour market for disabled persons, but the negative ones are segregation and isolation of disabled workers (cf. Visier, 1998), which can be prevented by creating sheltered employment (such as the opportunity offered by Samhall in Sweden) with a clear prospect of ensuring the worker's smooth transition to a regular job.

In addition to sheltered employment, it is important to introduce elaborate and well-designed activation policies for disabled job seekers, which place particular emphasis on availability of job assistants for disabled and promote availability of training and further education or specialization (as illustrated by the examples from Sweden and Denmark). Finally, disabled jobseeker should be provided ongoing support in advancement of professional skills. We cannot develop an inclusive society without providing activation measures for disabled persons, who are often marginalized and socially excluded. 


\subsection{Wage Subsidies}

\subsubsection{Croatia}

In addition to the already described internship program wage subsidy, another subsidized employment program in Croatia is the program for permanent seasonal workers. It was created with the aim to provide subsidy to employers of workers who are employed only during the seasonal work, and who can use subsidy during the period when they are not actually working. The measure is available to employers from all industries who have periods of reduced workload during the year due to the seasonal nature of the business. This measure can last six months, with the possibility of extension for the duration of the special circumstances caused by COVID-19.

\subsubsection{Sweden}

In Sweden, subsidized employment is available through two activation programs. In the first program, the employer receives a wage subsidy for the employment of long-term unemployed persons or newcomers, who become an extra resource for an employer in the welfare sector, the public sector, cultural sector, or nonprofit sector. In the second program, new start-up jobs are offered for long-term unemployed persons who have been away from working life because of illness or other reasons. The employer receives a contribution towards the salary(Swedish Public Employment Service, 2020).

\subsubsection{Denmark}

In Denmark, subsidized employment entails wage subsidies for public or private employers to re-train the professional and social competences of unemployed people. Wage subsidies in the private and the public sector are provided to employers when they hire a person who has been unemployed for at least 6 months. Public and private companies are eligible for a wage subsidy if they hire an unemployed person for a period of 4 or 12 months, depending on the category of unemployment (Danish Public Employment Service, 2020).

\subsubsection{Comparative analysis}

In addition to subsidies applicable to employment of youth, the active labour market measure in the form of wage subsidies is frequently used to support employment of jobseekers who are not easily employable, due to long-term unemployment, age, illness or other reason. While in Denmark and Sweden wage subsidies are used to support employment of long-term unemployed, in Croatia 
that category of jobseekers was formerly included in activation measures, but this is no longer the case. In 2019, 15.9\% of jobseekers were unemployed for 12 months or longer, while $13.9 \%$ of jobseekers were unemployed for 24 months or longer (Croatian Bureau for Statistics, 2020), which means that we had almost $30 \%$ of long-term unemployed persons. It is unlikely that this rate has been reduced lately. The Danish approach to the term "long-term unemployment" is particularly interesting because it starts six months after the start of unemployment. This is in line with Danish early intervention strategy (previously described in the sub-section on youth activation measures), which clearly shows the commitment to implementing the activation policy as early as possible because it is only then that it can lead to employment of a jobseeker.

The Swedish approach is even more comprehensive because it differentiates between the long-term unemployed persons and those who are away from the labour market for justified reasons preventing them from working. The first activation program has excellent "selling point" for employers because jobseekers are labelled as "additional resource" for employers; in effect, this is what subsidized employment is, but it is not often advertised like that. This presentation of a jobseeker as an additional resource has a significant impact on social inclusion, given that the long-term unemployed persons are often stigmatized and marginalized due to their inability to get a job. The selection of sectors of employment eligible for such wage subsidies (welfare, public sector, cultural sector or non-profit sector) points to the commitment of the Swedish government to support sectors with lower wages and less interest in employment.

In Scandinavian examples, we should also take into consideration the equal availability of wage subsidies for all public and private employers. In Croatia, a clear and unfair distinction was made between wage subsidies for internships in the private sector (eligible only for $50 \%$ wage subsidy) and public sector (eligible for $100 \%$ wage subsidy). It is difficult to understand and justify a very dissuading policy of employment incentives only in the public sector, knowing that an increasing number of professions are eligible for employment only in the private sector due to the nature of specific jobs. Furthermore, the non-profit sector cannot offer wages at the same level as private employers; therefore, it should be additionally supported to participate in youth internships as a less attractive sector of employment. Finally, it seems that the primary goal of such measures was not to have efficient labour market policies and increase employability of jobseekers but rather to establish unjustified preferential treatment of public offices.

In Croatia, the selection of partial wage subsidies in the tourism sector is closely linked to the importance of tourism revenues for the country. But, taking 
into consideration the problems of long-term unemployment and existence of a large group of difficult-to-employ jobseekers in other sectors, it is difficult to find justification for inclusion of the seasonal sector in wage subsidies activation programs as, in its substance, it is not an activation program but rather another type of supported program.

\subsection{Support for Self-Employment}

\subsubsection{Croatia}

The Croatian active labour market program on self-employment aid includes financial support granted to unemployed persons who are registered as unemployed, and who decide to start their own business. Business expansion grants are granted to businesses which are expanding their existing business, and which have already received self-employment support. Financial support can be received for a period of 24 months (in the first 12 months, the beneficiary needs to justify the support; in the remaining 12 months, the support is used for the maintenance of business activity); but, the financial support is provided only for some predetermined employment sectors. The measure can be combined with on-job training, and the applicant needs to submit a sustainable business plan (Croatian Public Employment Service, 2020).

\subsubsection{Sweden}

Sweden has an activation program for the self-employment of unemployed persons. The Employment Service pays a contribution to start-up costs (purchase of equipment or other costs) at the start of a profitable business. The requirement for receiving the contribution is the submission of a good business plan and relevant experience, consideration of the labour market needs, and competition in chosen industry. An interesting aspect of this measure is the possibility to benefit from an initial work placement aimed at increasing one's work experience in the industry where the applicant wants to work. If a jobseeker has never run a business prior to the application for a grant, the Employment Service offers information meetings, consultancy, and a start-up course to help the jobseeker describe his/her business concept, draw up a budget for the business, and learn about taxes, accounting, marketing, and similar important business aspects. For disabled persons with reduced work capacity, an additional requirement is to have a sound business plan of at least three years, while all other requirements and applicable rights are the same as for persons without disability (Swedish Public Employment Service, 2020). 


\subsubsection{Comparative analysis}

The Croatian activation measure for self-employment is used to promote and support employment in sectors that are of interest to the state; thus, it cannot be fully qualified as self-employment, given that the range of beneficiaries largely depends on the state decision which sectors are to be funded. While the Croatian self-employed persons can benefit from on-job training, the Swedish concept is to support the initial work placement in order to increase work experience in the sector where the activation measure is applied. Even if the applicant does not have relevant experience in the specific sector, there is a high likelihood of receiving funding even for an entrepreneurial idea, which clearly reflects the Swedish government support to start-up businesses. Thus, if we continue to approach self-employment from the old-fashion perspective of giving priority to applicants with specific work experience in the sector, which is the case in Croatia, we will not be able to move forward and support innovative business concepts through entrepreneurial activation measures.

\subsection{Education and Training Support}

\subsubsection{Croatia}

Croatia has two sets of active labour market measures aimed at providing education to unemployed persons, as well as to employed persons. These measures are aimed at increasing the level of employability of unemployed persons by providing relevant vocational training, re-training or advanced training programs in the required occupations in accordance with the development of the labour market, or raising the employability and competitiveness of persons without completed primary school by creating conditions for completing primary education and acquiring the first professional qualification.

As for already employed person, the goal of active labour market measure is to increase the level of competitiveness and expertise of employees by referring them to vocational training, re-training or advanced training programs in accordance with the development of the labour market. In addition to financing the full cost of education and medical examinations, the measure also covers transportation costs and financial assistance.

Another activation program is on-the-job training; this measure is aimed at training unemployed persons to acquire practical knowledge and skills needed to perform the tasks in a particular job, which may result in obtaining a certificate of entrepreneurial support institution (business incubators and development agencies), an employer's confirmation of acquired knowledge and skills, or an 
official public document (training certificate) (Croatian Public Employment Service, 2020).

\subsubsection{Sweden}

Sweden has several activation measures aimed at providing education and training opportunities to unemployed persons. These measures include: labour market training (tailor-made together with a specific employer, which often leads to employment); student support for education at primary and secondary school level; and student aid with grants and loans for studies in adult education, public high schools, universities or vocational universities, and certain courses abroad. Vocational introductory employment is available for those under the age of 25, long-term unemployed persons or newcomers to Sweden, where jobseekers may learn a trade or profession, get experience, get paid, and increase their chances of getting a job (Swedish Public Employment Service, 2020).

\subsubsection{Denmark}

In Denmark, education, guidance and upgrading of skills may include brief guidance and clarification activities, education and training (certified informal educational institutions, specifically arranged projects, and training periods). Unskilled unemployed persons over the age of 30 who receive unemployment benefits are given a chance to apply for and complete one of the 107 vocational training programmes. The curiosity of this program is that unemployed persons have to "pay" for these vocational programmes with a cut in their unemployment benefit. A loan is offered to allow unemployed people to draw the full rate of unemployment benefit for the duration of their course of education. This loan is to be repaid upon completion of the course of education.

Unemployed people over the age of 30 are eligible for an assessment of their non-formal and informal competences; the assessment is aimed at giving credit for competencies acquired through education, on the labour market, or from activities pursued in one's spare time. Recognition of prior learning by competence assessment programme will also support the individual training plan, including one or several adult vocational training programmes.

Denmark also implements job rotation scheme; thus, a company benefits if it supports the employees' continuing professional training and, at the same time, temporarily employs an unemployed person as a substitute. The temporary employee is required to have been unemployed for a minimum of six months, and is permitted to work as a temporary employee for up to six months. 
Employers can obtain subsidies for upgrading employees' skills through employment. A condition for granting subsidies is that the upgrading of skills goes beyond what the employer would normally be required to provide (for example, on-the-job training schemes or work tools that are specific to the individual employer). Unemployed persons under the age of 30 or people who are at risk of becoming long-term unemployed persons can get into the scheme after six months of unemployment.

Finally, Denmark also has the right to six weeks' job-oriented vocational training (from the first day of unemployment) for low-skilled and skilled unemployed people who are members of an unemployment insurance fund. In this training, participants are provided with relevant skills and competences required in the labour market; the training is primarily aimed at specific sectors and job functions. Social partners play a major role in determining which specific adult vocational training programmes are offered (Danish Agency for Labour Market and Recruitment, 2020).

\subsubsection{Comparative analysis}

Vocational trainings are one of the most common activation measures, which are used in majority of countries implementing active labour market programs. The problem with vocational trainings is the low commitment of unemployed persons to participate in additional training; this issue may be counteracted by introducing the obligation to participate in training costs (as illustrated in the example of the Employment Service in Denmark, where the costs of vocational training are deduced from the unemployment benefits). This actually has multiple benefits because it sends a message to jobseekers that additional training brings additional value to their professional competencies and, as such, needs to be paid for; it also empowers jobseekers to move from the position of passive recipients of income-substitute benefits and vocational training to the position of active members of society who are able to contribute towards their specialization; finally, considering the financial implications for the jobseeker, it entails a more serious approach to participation in the training.

On the other hand, we also have frequent resistance of employers to allow their employees to participate in professional trainings, primarily for fear that it may have negative implications for the work process. In that regard, the Danish innovative strategy is substitute worker practice, which encourages training of present employees and concurrently provides an opportunity to unemployed persons to get employed on a temporary basis. 


\subsection{Specific Measures Related to the Impact of Covid-19 Pandemic on the Labour Market in Croatia}

In March 2020, Croatian authorities adopted an ad hoc active labour market measure to support job retention due to Covid-19 lockdown. The initial threemonth wage subsidies were implemented in a rather chaotic manner, but they did not explicitly regulate the prohibition of dismissal within a certain period after awarding the wage subsidy. After the expiry of the wage-subsidy period, a large number of dismissals ensued in the tourism sector. The subsequently adopted package of new activation measures was expanded to include job retention measures for micro-entrepreneurs, introduction of subsidized short-time work, and support for retention of sheltered workplaces, integrative workplaces and work units for employment of disabled persons. Currently, wage subsidies include the following sectors: passenger transport, accommodation, food and beverage preparation, administrative and support service activities, event industry, arts, entertainment and recreation, micro-entrepreneurs and all other employers who cannot work or whose work has been restricted. The requirement is that their income has decreased by at least 50 or 60 percent.

Short-time work was introduced as a new activation measure, with the aim of preserving jobs for employers whose work has been temporarily reduced due to the pandemic. Employers who employ more than 10 workers can benefit from this measure, but only if they can prove that they have a decline in revenues and the number of employed workers due to the pandemic. The subsidy amounts to the equivalent of 266,00 EUR. The employer is prohibited to terminate the employment contract of the employee on whose behalf the support has been obtained at least 30 days from the day of termination of the use of the support.

Given that there are no available data on the use of this measure, we can notice several structural problems at the very beginning of implementing this measure, which might eventually lead to a low rate of using this activation program. The first possible issue is a flat rate subsidy amount which could be attractive only in lower paid sectors of employment, and will not be used for retention of higher skilled and higher paid workers. Secondly, the application procedure seems overly complicated, with employers being requested to prove several different things, such as a link between the drop in revenues and working hours and Corona-virus lockdown. Thirdly, the employer is obliged to pay all contributions for the subsidized support, which may discourage employers to use this measure. If we look into the Swedish experience with Covid-19 response, their Government proposed a system of support for short-term layoffs, with the aim of ensuring the survival of more businesses and dismissal of fewer employees. In order to achieve this, the Government introduced a temporary reduction of employers' 
social security contributions and the general salary contribution for the first 30 employees and self-employed people for four months, along with full coverage of employers' sick pay costs. Measures on a temporary increase of the number of people entitled to unemployment benefits and on a temporary increase in benefit levels were introduced in 2020.

In the Budget Bill for 2021, the Government proposed funding for increased access to employment training programmes and announced the introduction of an 'intensive year' for newly arrived immigrants, which will help them enter the labour market more quickly. It also proposed the allocation of funds for introductory jobs and extra jobs, aimed at creating more job opportunities for newly arrived immigrants and long-term unemployed persons, which may in turn strengthen their position in the labour market (Government of Sweden, 2020).

\section{Conclusion}

Active labour market policies are not only a powerful tool for employment but also a very important tool for social inclusion, education and empowerment of jobseekers. Activation programs need to be developed with a great deal of social responsibility, taking into consideration the complexities of the labour market, the complex structure of unemployed labour force, as well as the correspondence between labour market needs and jobseekers' education attainments, professional skills and competencies.

The second crucial phase is the implementation of activation measures because their inadequate implementation can be more detrimental to the labour market than the absence of any measures. Namely, if procedures are not streamlined and simplified, activation measures will not be used and will not achieve the intended purpose of (re)integration of a jobseeker into the labour market.

The third crucial phase is the evaluation of effectiveness of each labour activation measure and its impact on employability and/or professional competencies of a jobseeker. This assessment is probably the central part of active labour market programs because, without in-depth analysis of their impact, they remain just an expensive attempt to increase level of employment and justify the existence of usually robust state employment service.

The paper has attempted to provide comparative analysis of the most used activation measures in three European countries: Sweden and Denmark as the most advanced countries and Croatia, one of the least advanced countries in terms of active labour market policies. The last analysis on the impact of activation measures by Croatian Public Employment Service was done for the period 2010 - 2013, which means that we did not have a comprehensive analysis of labour 
activation measures for the past seven years. In the meantime, the Covid-19 crisis severely affected (un)employment rates and now, more than ever before, we need to use comparative examples of well-functioning, well-developed, innovative and inclusive labour activation programs. Danish and Swedish labour activation programs certainly qualify for that description.

\section{References}

Calmfors, L., Forslund, A., Hemström, M. (2001). Does Active Labour Market Policy Work?, Swedish Economic Policy Review 85,pp. 61-124.

Croatian Public Employment Service (2020), retrieved 15 October 2020 from https://www.hzz.hr/usluge-poslodavci-posloprimci/.

Croatian Bureau of Statistics (2020). Labour Force Survey for 2019, retrieved 07 October 2020 from https://www.dzs.hr/Hrv_Eng/publication/2020/09-02-07_01_2020.htm

Croatian Bureau of Statistics (2018). Labour Force Survey for 2017, retrieved 07 October 2020, from https://www.dzs.hr/Hrv_Eng/publication/2018/09-02-07_01_2018.htm

Danish Agency for Labour Market and Recruitment (2020). Active labour Market Policy Measures, retrieved 15 October 2020 from https://www.star.dk/en/ active-labour-market-policy-measures/

Gilbert, N., Von Voorhuis, R. (eds.) (2001). Activating the Unemployed, Transaction, New Brunswick, in Spicker, P. (2015),Social Policy: Theory and Practice, UK. Policy Press, University of Bristol.

Griggs, E. (2014). Work and Employment Policy, in: Bochel, H., Daly, G. (eds.) Social Policy, Abingdon, Routledge, pp. 225-43.

Government of Sweden (2020), retrieved 05 October 2020 from https://www. government.se/articles/2019/09/measures-to-get-more-people-into-work/ https://www.government.se/articles/2020/09/labour-market-initiatives-inthe-budget-bill-for-2021/ https://www.government.se/articles/2020/04/the2020-spring-budget-in-five-minutes/

Hudson, J., Kuhner, S., Lowe, S. (2015). The Short Guide to Social Policy, UK. Policy Press. University of Bristol.

Hill, M., Irving, Z. (2020). Exploring the World of Social Policy: An International Approach, UK Policy Press. University of Bristol. 
Hill, M., Irwing, Z. (2009). Understanding Social Policy ( $8^{\text {th }}$ ed.), Malden, MA, Wiley-Blackwell.

Hrvatski zavod za zapošljavanje, Ipsos (2016).Vanjska evaluacija mjera aktivne politike tržišta rada 2010-2013.

Hrvatski zavod za zapošljavanje (2019). Mjere aktivne politike zapošljavanja iz nadležnosti Hrvatskoga zavoda za zapošljavanje: Uvjeti i načini korištenja sredstava za provođenje mjera u 2020. godini.

Hrvatski zavod za zapošljavanje (2020). Priopćenje za javnost: Promjene u evidentiranoj nezaposlenosti tijekom rujna te stanje registrirane nezaposlenosti na kraju rujna 2020. godine, retrieved 01 October 2020 from https://www.hzz.hr/ content/stats/0920/HZZ_PR-Nezaposlenost-Zaposljavanje-9-2020.pdf

Immervoll, H., Scarpetta, S. (2012). Activation and employment support policies in OECD countries: An overview of current approaches, Journal of Labour Policy, $1: 9$.

Immervoll, H., Knotz, C. (2018). How Demanding are Activation Requirements for Jobseekers, OECD Social, Employment and Migration Working Papers No. 215, retrieved 04 October 2020 from https://dx.doi.org/10.1787/2bdfecca-en

Korpi, T. (1997). Is utility related to employment status? Employment, unemployment, labor market policies and subjective well-being among Swedish youth, Labour Economics 4, 125-147, in Calmfors, L. Forslund, A. Hemström, M. (2001) Does Active Labour Market Policy Work?, Swedish Economic Policy Review 85, pp. 61-124.

Obadić, A. (2003). Utjecaj aktivnih i pasivnih politika na tržište rada, Financijska teorija i praksa 27 (4) str. 529-546.

OECD (2019). Labour Market Policies Interventions for the Long Term Unemployed: In-Depth Evaluation, Retrieved 05 October 2020 from https://www.oecd.org/ els/emp/LMP\%20interventions\%20for\%20LTU\%20-\%20in-depth\%20evaluation.pdf

Pignatti, C., Van Belle, E. (2018). Better together: Active and Passive Labour Market Policies in Developed and Developing Economies, International Labour Organization, Working Paper No 37.

Pravobranitelj za osobe s invaliditetom (2020). Izvješće o radu Pravobranitelja za osobe s invaliditetom 2019, Retrieved 05 October 2020 from https://posi.hr/ wp-content/uploads/2020/04/Izvješće-o-radu-POSI-za-2019.pdf .

Samhall (2020). Retrieved 08 October 2020, from https://samhall.se/in-english/ 
Spicker, P. (2015). Social Policy: Theory and Practice, UK. Policy Press, University of Bristol.

Swedish Public Employment Service (2020). Retrieved 10 October 2020 from https://arbetsformedlingen.se/other-languages/english-engelska/extra-stod/ stod-a-o.

Visier, L. (1998). Sheltered employment for persons with disabilities, International Labour Review, Vol. 137, No 3, Retrieved 03 October 2020 from https:// www.ilo.org/public/english/revue/download/pdf/visier.pdf

Vlandas, T. (2013). Mixing Apples with Oranges? Partisanship and Active Labour Market Policies in Europe, Journal of European Social Policy, 23 (1); 3-20.

Doc. dr. sc. Helga Špadina,

Docent Pravnog fakulteta,

Sveučilište Josip Juraj Strossmayer u Osijeku,

Republika Hrvatska

\section{ODGOVORNE SOCIJALNE POLITIKE: UPOREDNA ANALIZA HRVATSKIH, ŠVEDSKIH I DANSKIH MERA AKTIVNE POLITIKE ZAPOŠLJAVANJA}

\section{Rezime}

Rad se bavi uporednom analizom hrvatskih, švedskih i danskih mera aktivne politike zapošljavanja u području podrške mladima, osobama sa invaliditetom, dugoročno nezaposlenima, kao i mera subvencija zarada za određene kategorije zaposlenih, subvencija za samozapošljavanje i obrazovanje, te provođenja programa profesionalnog usavršavanja kao pripreme za ulazak na tržište rada. Zbog uticaja Covid-a 19 na stopu nezaposlenosti na tržištu rada, moramo se usredsrediti na uporedne primere funkcionalnih, dobro razvijenih, inovativnih i inkluzivnih programa aktivnog traženja posla na tržištu rada, kao što su švedski i danski.

U radu su analizirane prednosti mjera aktivnog traženja posla sa detaljnom procenom nivoa kompetencije za tražioce zaposlenja bez prethodnog iskustva, kao i koristi od uključivanja neregistrovanih tražioca zaposlenja u programe aktivnog traženja posla i stručnog osposobljavanja. Takođe se ukazalo da se negativni ishodi tzv. zaštićenog zapošljavanja osoba sa invaliditetom mogu sprečiti stvaranjem programa sa jasnom perspektivom prelaska zaposlenih osoba sa invaliditetom na redovan posao. Razrađene i dobro osmišljene aktivne politike tržišta rada za osobe sa invaliditetom koje traže posao takođe treba da uključuju angažovanje pratilaca 
za posao za zaposlene sa invaliditetom, dostupnost programa stručnog osposobljavanja, dalje obrazovanje ili specijalizaciju, i kontinuiranu podršku u unapređenju profesionalnih veština.

U radu se naglašava važnost strategija rane intervencije i predstavljanje dugoročno nezaposlenih kao „dodatnog resursa“ za poslodavce koji primaju subvencije za njihove zarade jer se tako sprečava stigmatizacija i marginalizacija navedenih lica. Konačno, mogućnost dobijanja sredstava za preduzetničku ideju za čiju realizaciju tražilac zaposlenja nema relevantno iskustvo vrlo je napredna jer pokazuje podršku idejama za osnivanje preduzeća. U radu se ističe da se socijalna inkluzija nezaposlenih može postići i njihovim učešćem u troškovima stručnog osposobljavanja, te da poslodavci mogu biti motivisani da zaposlenima omoguće stručno usavršavanje ako su obezbeđeni zamenski radnici. Rad se završava kratkim pregledom najnovijih politika aktivnog traženja posla na tržištu rada uzrokovanim pojavom virusa Covid-a u Hrvatskoj.

Ključne reči: aktivna politika tržišta rada, aktivacijske strategije, nezaposlenost, socijalna politika, Covid-19. 
